\title{
Mariqual Model: A Survey Instrument Developed For Marital Quality Conceptualized From Servqual Model
}

\author{
Huam Hon Tat, Anantha Raj A Arokiasamy, Ng Kim Soon
}

\begin{abstract}
Marriage has been described as the most important and fundamental human relationship in our lives. Indeed, marital adjustment, happiness, satisfaction and other terminologies that related to the relationship subjective quality of marriage have been some of the most popular topics of these fields. Research on the marital relationship has been one of the most frequently studied areas of investigation in the family and marriage field. The literature about marital quality reveals that scholars have endeavored to gauge and describe variation in a construct that is itself barely grasped. Despite a plethora of adequate instruments available as measures of marital quality, however, there is still lacking an approach, which can increase theoretical simplicity and at the same time prevents some of the perplexes apparent in the experimental literature. This paper describes the development of an instrument called MARIQUAL conceptualized from the 22-item instrument (called SERVOUAL) used for evaluating customer experiences of service quality in business organizations. Even though there have been many criticisms of the SERVQUAL model, service quality literature still suggests that SERVQUAL model has been the main standard model applied to assess and operate service quality around various service locales and numerous cultural environments and is prized by scholars and experts. Additionally, it has good reliability and provides a suitable measurement for perceived service quality. The paper concludes with a recommended survey instrument for marital quality conceptualized from the SERVQUAL Model
\end{abstract}

Index Terms: MARIQUAL, SERVQUAL, Marital Quality, Service Quality

\section{INTRODUCTION}

Matrimony is known to have shielding advantages regarding bodily, emotional, and mental wellbeing (Carr \& Springer, 2010). It has been described as the most important and fundamental human relationship in our lives (Larson \& Holman, 1994). Marital adjustment, happiness, satisfaction and other terminologies that related to the relationship subjective quality of marriage have been some of the most popular topics of these fields (Burr, 1967; Spanier \& Lewis, 1980). The nature of the marriage relies upon numerous elements (Chemielewska, 2012, for example, an emotional feeling of fulfillment of life partners, the development to wed, explanations behind picking a life partner, major consistence frames of mind towards esteems and character characteristics, and so on. To be sure, marital quality is a significant part of family life that shapes individuals' wellbeing and prosperity (Allendorf and Ghimire, 2012).

Revised Manuscript Received on April 19, 2019.

Huam Hon Tat, Putra Business Schoo, UPM Serdang, Selangor, Malaysia

Anantha Raj A Arokiasamy, Xiamen University Malaysia,Sepang,Selangor, Malaysia,

Ng Kim Soon, Universiti Tun Hussein Onn Malaysia, Johor, Malaysia
Marital quality alludes to an assessment of matrimonial fulfillment and marital change of marriage accomplices (Obradović and Čudina-Obradović, 1998). It incorporates positive encounters, for example, feeling adored, thought about, and fulfilled in a relationship, just as negative encounters, for example, requests from one's life partner and matrimonial clashes (Čikeš, Marić and Šincek 2018; Umberson and Williams, 2005).

The literature on marital quality has been one of the most frequently studied areas of investigation in the family and marriage field. Marital quality describes the extent of contentment, confidence, admiration and attention partners share in their affiliation (Falcke, 2003). Despite a plethora of adequate instruments available as measures of marital quality, however, to the researchers' knowledge, there is still lacking an approach, which can increase theoretical transparency and at the same time prevents some of the perplexes obvious in the experiential literature. At this juncture, the researchers discover that expectation disconfirmation theory conceptualized by Oliver (1980, 1997) could be a useful approach to be adapted when measuring marital quality. Undeniably, hopes have been documented as an significant factor of customer conduct (Sheth \& Mittal, 2004), particularly marketing researchers have been considered both as assessment standards in postbuying experience (Oliver, 1980; Parasuraman, Zeithaml, \& Berry, 1988, 1991) and as brand name or item beliefs in prebuying judgment process (Fishbein \& Ajzen, 1974, 1975; Olsen \& Dover, 1979). In the context of marriage, the expectations of a spouse are not stable over time and it is normally a partner's expectation rating of a marriage element rises with that passage of time since their initial marriage. Additionally, the expectations approach has suggested the likelihood that elevated contentment could include low anticipations rather than merely wellfunctioning services. In distinction, low contentment could include not merely inadequately working service but high anticipation (Oliver, 2007).

Notwithstanding the ubiquity and proceeded with utilization of the SERVQUAL scale, it comes with criticisms (Kar, 2016). For example, faultfinders have addressed whether the five nonexclusive components of the scale and its psychometric properties are commonly pertinent in all service setting (Ladhari, 2009). In addition, various genuine reactions have likewise been raised

Published By:
Blue Eyes Intelligence Engineering

\& Sciences Publication 
concerning its legitimacy, especially on the conventional idea of the service quality measurements and the utilization of wanted desire as an examination standard (Yoon and Ekinci, 2003). Buttle (1996) likewise shown that an attitudinal model for service quality is increasingly proper contrasted with expectation disconfirmation model utilized in SERVQUAL.

This model has been condemned on various grounds, including the disappointment of numerous analysts to imitate the first SERVQUAL factor structure and the unreasonable idea that buyers can frame assumptions regarding service when they have minimal earlier learning about the item (O'Neil and Palmer. 2003). Unmistakably, SERVQUAL has been exposed to various hypothetical and operational reactions. Be that as it may, it is as yet a prominent service quality determinant because of its better indicative limit over option logical systems (Kim, Kim and Yun, 2003). Since service quality is resolved based on the SERVQUAL measurements, and the way that its measurements vary in significance to the client crosswise over societies, nations, and enterprises, and explicitly, it is imperative to discover which measurements are considered as most significant by clients in a specific setting, to organize service improvement venture choices, given the restricted assets accessible to the board (Tegambwage, 2017, p. 76).

In addition, the willingness to provide high-quality services plays an important role in service industries, which makes its measurement and its subsequent management of utmost importance (Poor, Poor, \& Darkhanch, 2013; Shekarchizadeh, Rasli \& Huam, 2011, Zaim, Bayyurt, \& Zaim, 2010). Today, SERVQUAL is as yet viewed as a vigorous scale for estimating service quality crosswise over administration areas. Albeit a few commentators have expressed that the recognition scores give a superior proportion of service quality than the gap scores, in any case, the gap scores are commonly increasingly valuable in recognizing territories of shortcoming and quality of life partner (Ladhari, 2009). Such gap scores can help a spouse to diagnose where improvements should be targeted. This paper intends to summarize and synergize the literature that provides arguments for and against the proposed MARIQUAL model in measuring marital quality based on the conceptualization of SERVQUAL model initiated by Parasuraman, Zeithaml and Berry (PZB) (1985).

\section{LITERATURE REVIEW}

\section{A. $\quad$ Marital Quality}

Single person marital behavior and broad matrimony models have long been of curiosity to family scholars, demographers and public policy specialists (Barr \& Simons, 2012). In the arena of domestic research specifically, earlier researches have made great advances toward comprehending the association among matrimonial dispute and quality (Ahmadi, Rezazade, Saadat, Kimiaei, \& Zade, 2015). Study on marital quality has been of great concern among researchers, especially since the increasing number of divorce around the world (Firdaus Abdul Razak, Mohd Hoesni, Zakaria, \& Ismail, 2015). For example, according to Syariah Judiciary Department in Malaysia, the number of divorce rate reported in 2010 was 41,809 and increased to 53,891 in 2014. Ostensibly the least difficult clarification for why a marriage breaks up is that one or the two life partners become progressively disappointed, decreasing the nature of couple connection and inciting a division or separation thusly. In this unique situation, family analysts have been creating measures to evaluate the nature of the conjugal relationship for more than six decades (Schoebi, Karney, Bradbury, 2011).

The expression "marital quality" has been utilized to allude to ideas and measures that in the past have been called marital change, fulfillment, and joy (Spanier and Lewis, 1980). Marital fulfillment and satisfaction both allude to emotional assessments of beneficial outcome in the marital relationship by one (or both) of the companions (Johnson, 1995). Marital change implies both social and evaluative parts of a marital relationship. These incorporate dyadic attachment, fulfillment, agreement, relational strains, and inconvenient dyadic contrasts (Spanier, 1976). As verified by Chonody, Gabb, Killian, and Dunk-Wes (2018, p. 920), seeing how people make enduring coupledom are, hence, significant for both research and practice, and estimating marital quality is a basic angle.

As marital quality is characterized as a worldwide assessment of the marriage along a few measurements (Fincham and Bradbury, 1987), high marital quality is normally operationally characterized by high self-announced fulfillment with the relationship, transcendently inspirational frames of mind towards one's accomplice, and low degrees of unfriendly and negative conduct. Despite what might be expected, low marital quality is described by low fulfillment, dominatingly negative frames of mind towards one's accomplice, and abnormal amounts of unfriendly and negative conduct (Robles, Slatcher, Trombello, and McGinn, 2014). All in all, past examinations show that marital quality, fulfillment, and change are for the most part exceedingly connected, demonstrating that these are maybe parts of one idle developement (Fincham and Bradbury, 1987). In this way, outline of an operational definition combined with thorough psychometric testing may propel another scale for this substantive space (Chonody, Gabb, Killian and Dunk-Wes, 2018).

\section{B. SERVQUAL Model and Its Applications}

The PZB's model of service quality, specifically SERVQUAL has been filled in as a significant instrument in estimating service quality in the advertising writing. In 1988, they built up this model to gauge client's desires and view of service quality, which is a 22 item instrument dependent on five measurements having distinctive service quality characteristics. PZB gathered the things into the accompanying five particular measurements: effects (physical offices, hardware and presence of faculty), trustworthiness (capability to play out the certain service continually and surely), receptiveness (eagerness to support customers and give brief service), confirmation (info and politeness of workers and capability to motivate faith and 
inevitability) and sympathy (caring, customized attention the firm provides its customers) (Parasuraman et al., 1988, p. 6). The tool is conceptualized as a hole between what the clients expect and their assessments of the presentation of a service (Parasuraman, Berry, and Zeithaml, 1991; Parasuraman, Zeithaml, and Berry, 1986, 1988; Zeithaml, Berry and Parasuraman, 1993).

As such, execution to-desires "gaps" on credits that clients use to assess the nature of service structure the hypothetical establishment of SERVQUAL (Asubonteng, McClearly and Swan, 1996). PZB's conceptualization sets that aspirations, blended with apparent execution, lead to post-buy satisfaction. This effect is mediated through positive or negative disconfirmation among aspirations and implementation. As expressed in the disconfirmation of desire model, sentiments of fulfillment emerge when shoppers contrast their impression of item execution with their desires (Oliver, 1980; Spreng, Mackenzie and Olshavsky, 1996). At the end of the day, disconfirmation is guessed to influence fulfillment, with positive disconfirmation prompting fulfillment and the other way around. In truth, PZB's model of service quality, to be specific SERVQUAL is an unmistakable model from showcasing writing that has been connected in anticipating and clarifying customers' fulfillment.

SERVQUAL is recognized on the viewpoint that the client's assessment of service quality is fundamental. The service quality progress has been altered and disentangled by the US way of thinking, in particular Parasuraman, Zeithaml and Berry (PZB), wherein 1985, they suggested that powerful service quality ought to have ten clear measurements, to be specific (1) dependability; receptiveness; (3) skill; (4) get to; (5) cordiality; (6) correspondence; (7) believability; (8) security; (9) understanding/knowing the client; (10) physical assets. In any case, in their 1988 work these parts were fell into five measurements, to be specific effects (physical offices, gear, and presence of specialists), unwavering quality (capacity to play out the guaranteed service constantly and precisely), responsiveness (readiness to support client and give brief service), affirmation (information and politeness of laborers and their capacities to move trust and certainty), and compassion (minding, individualized consideration the association gives its clients) (Ismail and Mohd Yunan, 2016; Parasuraman, Berry and Zeithaml 1991, 1994). Dependability, effects, and responsiveness stayed particular, yet the staying seven segments fallen into two total measurements, confirmation, and sympathy.

Specifically, SERVQUAL model has been utilized to measure service quality in a diversity of service businesses, including the higher education, healthcare sector, banking, fast food, telecommunications, retail chains, information systems, library services, car servicing, airline catering, computer services, ophthalmological services, mental health services, local government, recreational services, accounting firms, business-to-business channel partners (e.g., Arokiasamy, 2014; Arokiasamy \& Abdullah, 2013; Asghari, \& Babu, 2018; Buttle, 2006; Chiang, \& Perng, 2018; Hartwig \& Billert, 2018; Hisham, Sanyal, \& Ahmad, 2016; Ismail \& Mohd Yunan, 2016; Khattab, 2018; Ladhari, 2009; Leonnard, 2018; Markovic, \& Raspor, 2010; Michael,
Folinas, \& Rotsios, 2015; Muhammad Butt, M., \& de Run, 2010; Neupane \& Devkota, 2017; Ok, Suy, Chhay, \& Choun, 2018; Ok, \& Hengsadeekul, 2018; Pamatmat, Dominguez, Pamin, \& Daran, 2018; Patterson, Johnson, \& Spreng, 1997; Rehaman \& Husnain, 2018; Saghier, 2015; Shekarchizadeh, Rasli \& Huam, 2011; Spreng \& Page, 2003; Syahir \& Hudrasyah, 2014; Yarimoglu, 2014).

\section{DISCUSSION \& RECOMMENDATION}

Based on previous literature, marital quality is believed to be a multidimensional construct. To a certain extent, marital quality is supposed to be influenced by various aspects, such as how couples respond to their stress and achieve mutual understanding (Firdaus Abdul Razak, Mohd Hoesni, Zakaria, \& Ismail, 2015). Besides, marital quality alludes to the level of fulfillment, trust, regard and intrigue life partners share in their relationship, which demonstrates that it is multifactorial and along these lines, considers that join factors of individual assets of the life partners, their versatile procedures and their setting for understanding the marvel (Mosmann, Wagner, and Féres-Carneiro, 2006; ScorsoliniComin, and Santos, 2009) are essential (Scheeren, de Andrade Vieira, Ribeiro Goulart, and Wagner (2014).

In light of that, a large number of the current marital quality's scales may consider issue centered and additionally approved with an example of couples occupied with treatment in spite of the fact that the scales may serve a particular capacity. In this way, the present examination tries to make an option - an estimation scale got from execution to-desires "holes" on credits that companions use to assess the nature of service, which structure the hypothetical establishment of MARIQUAL. Clearly, PZB's conceptualization sets that desires, combined with apparent execution, lead to post-marital fulfillment. This impact is interceded through positive or negative disconfirmation among desires and execution, which is predictable with the disconfirmation of desire model, where sentiments of fulfillment emerge when people think about their impression of their accomplices' exhibition to their desires. Certainly, the ground-breaking job that desires can play on feelings was plot by Feather (1969), who proposed that people's impression of results as being either constructive or antagonistic are identified with their underlying desires for the result. As such, disconfirmation is theorized to influence fulfillment, with positive disconfirmation prompting fulfillment and the other way around.

Clearly, people will in general have assumptions about their marital connections (Dixon, Gordon, Frousakis, and Schumm, 2012). Also, the standard one uses to assess one's nearby persona; connections are dynamic in nature and can change dependent on one's encounters (McDonald, 1981). In Sabatelli's (1984) examine, he infers that a life partner's marital fulfillment is subject to whether his or her experience of the relationship falls above or underneath his or her correlation level. Furthermore, inquire about has additionally discovered that one's marital desires covary as 
International Conference on Recents Advancements in Engineering and Technology (ICRAET-18) |15th and 16th March 2019|Siddhartha Institute of Technology \& Sciences, Telangana, India.

an element of age (Sabatelli and Pearce, 1988). Clearly, the impact of a mate's desires may need to consider as a moderating variable in evaluating mate fulfillment. Furthermore, some traditional analysts, for example, the investigations of Grönroos (1982), Lewis and Booms (1983) and Smith and Houston (1982) asserted that fulfillment with services is identified with affirmation or disconfirmation of desires.

Thus, it is perhaps not surprising to state that delivering a spouse's marriage quality means conforming to a partner's expectations on a consistent basis. Furthermore, it is difficult to address the dilemma of overlapping item content with existing measures of marital quality. This dilemma, however, can be easily avoided by adopting expectation disconfirmation theory since it does not overlap in test items when its relationship to aspects of marital functioning is examined. Although some critics have stated that the perception scores provide a better measure of service quality than the gap scores, however, the gap scores are generally more useful in identifying areas of weakness and strength of spouse (Ladhari, 2009).

More importantly, such gap scores can help a spouse to diagnose where improvements should be targeted. Clearly, the theory of expectation disconfirmation within the marriage context deserves more treatment. The present study, therefore, intends to summarize and synergize the literature that provides arguments for and against the proposed MARIQUAL model in measuring marital quality based on the conceptualization of the SERVQUAL model. Given the above, this paper advances an instrument called MARIQUAL model (Table 1), which is a recommended survey instrument for marital quality, which is conceptualized from the SERVQUAL Model developed by $\mathrm{PZB}$ in 1988 .

Table 1: Recommended Questions for MARITAL Instrument

\begin{tabular}{|l|l|}
\hline Dimension & \multicolumn{1}{|c|}{ Question } \\
\hline Tangibles & Fashionable daily living style \\
\hline & Physical appearance is visually appealing \\
\hline & Appearance is consistent with life stage \\
\hline Reliability & Meets promised time-frames for response \\
\hline & $\begin{array}{l}\text { Sympathetic and reassuring, when } \\
\text { spouse has problems }\end{array}$ \\
\hline Responsiven \\
ess & $\begin{array}{l}\text { Expected to tell spouse exactly when the } \\
\text { task will be performed }\end{array}$ \\
\hline & \begin{tabular}{l} 
Krovides task at the times promised \\
\hline
\end{tabular} \\
\hline
\end{tabular}

\begin{tabular}{|l|l|}
\hline & $\begin{array}{l}\text { Reasonable to expect prompt action from } \\
\text { a spouse }\end{array}$ \\
\hline Always have to be willing to help a spouse \\
\hline Assurance & $\begin{array}{l}\text { Always not too busy to respond promptly } \\
\text { to spouse requests }\end{array}$ \\
\hline & Feels safe when interacting with a spouse \\
\hline A spouse should be polite \\
\hline Should get adequate support from spouse \\
to do a task well
\end{tabular}

\section{REFERENCES}

1. Ahmadi, K., Rezazade, M., Saadat, H., Kimiaei, S. A., \& Zade, N. H. (2015). Contribution of marital conflict to marital quality in short and long-term marriages: An actor-partner interdependence model. Journal of Education and Health Promotion, 4(42), 1-8.

2. Allendorf, K., \& Ghimire, D. (2012). Determinants of marital quality in an arranged marriage society. Population Studies Center, Institute for Social Research: University of Michigan, USA.

3. Arokiasamy, A. R. A. (2014). service quality on customer loyalty and intentions to switch in the airline industry in Malaysia. Australian Journal of Basic and Applied Sciences, 8(6), 279-284.

4. Arokiasamy, A. R. A., \& Abdullah, A. G. (2013). Service quality and customer satisfaction in the cellular telecommunication service provider in Malaysia. Journal of Arts, Science \& Commerce, IV(2), 1-9.

5. Asghari, S. \& Babu, H. (2018). Service Quality Gap and its Impact on the Performance of Indian Health Insurance Companies. Global Journal of Management and Business Research, 18(5), 18-41.

6. Asubonteng, P., McCleary, K. J. \& Swan, J. E. (1996) SERVQUAL revisited: A critical review of service quality. Journal of Services Marketing, 10(6), 62-81.

7. Barr, A. B., \& Simons, R. L. (2012). Marriage 
expectations among African American couples in early adulthood: A dyadic analysis. Journal of Marriage and Family, 74(August), 726-742.

8. Burr, W. (1967). Marital satisfaction: A conceptual reformation, theory and partial test of the theory. The University of Minnesota. Ph.D. dissertation.

9. Buttle, F. (1996). SERVQUAL: Review, critique, research agenda. European Journal of Marketing, 30(1), 8-32.

10. Carr, D., Springer, K. W. (2010). Advances in families and health research in the 21st century. Journal of Marriage and Family, 72, 743-761.

11. Chemielewska, M. (2012). Marital quality in the context of interpersonal dependency. Economics \& Sociology, $5(2), 58-74$

12. Chiang, T.-Y., \& Perng, Y.-H. (2018). A new model to improve service quality in the property management industry. International Journal of Strategic Property Management, 22(5), 436-446.

13. Chonody, J. M., Gabb, J., Killian, M., \& Dunk-West, P. (2018). Measuring relationship quality in an international study: exploratory and confirmatory factor validity. Research on Social Work Practice, 28(8), 920-930.

14. Čikeš, A. B., Marić, D., \& Šincek, D. (2018). Emotional intelligence and marital quality: Dyadic data on Croatian sample. Studia Psychologica, 60(2), 108-122.

15. Dixon, L., Gordon, K. C., Frousakis, N. N/, \& Schumm, J. A. (2012). A study of expectations and the marital quality of participants of a marital enrichment seminar. Family Relations, 61(1), 75-89.

16. Falcke, D. (2003). Águas passadas não movem moinhos? As experiências na família de origem como preditoras da qualidade do relacionamento marital (Unpublished doctoral dissertation). Pontifícia Universidade Católica do Rio Grande do Sul, Porto Alegre, RS.

17. Fincham, F. D., \& Bradbury, T. N. (1987). The assessment of marital quality: A reevaluation. Journal of Marriage and the Family, 49, 797-809.

18. Firdaus Abdul Razak, S. N., Mohd Hoesni, S., Zakaria, E, \& Ismail, R. (2015). The role of dyadic coping to marital quality - The conceptual paper. $2^{\text {nd }}$ Global Conference on Business and Social Science-2015 (GCBSS-2015), 17-18 September 2015, Bali, Indonesia. objects as predictors of single and multiple behavioral criteria. Psychological Review, 81, 59-74.

20. Fishbein, M., \& Ajzen, I. (1975). Belief, attitude, intention, and behavior: An introduction to theory and research. Reading, MA: Addison Wesley.

21. Grönroos, C. (1982), Strategic management and marketing in the service sector, Marketing Science Institute, Cambridge, MA.

22. Hamilton, G. V. (1929). Research in marriage. New York: Albert and Charles Boni.

23. Hartwig, K. \& Billert, M. S. (2018). Measuring service quality: A systematic literature review. In European Conference on Information Systems (ECIS). Portsmouth, UK.

24. Hisham, M. W., Sanyal, S., \& Ahmad, M. (2016). The impact of service quality on customer satisfaction: A study on selected retail stores in India. International Review of Management and Marketing, 6(4), 851-856.

25. Ismail, A., \& Mohd Yunan, Y. S. (2016). Service quality as a predictor of customer satisfaction and customer loyalty. LogForum. 12(4), 269-283.

26. Johnson, D. R. (1995). Assessing marital quality in longitudinal and life course studies. Retrieved from https://pdfs.semanticscholar.org/3778/1e39c45878ec839f 486376834bb979b873e8.pdf.
19. Fishbein, M., \& Ajzen, I. (1974). Attitudes towards

27. Kar, B. (2016). Service quality and SERVQUAL model: A reappraisal. Amity Journal of Operations Management 1(2), 52-64

28. Khattab, F. (2018). Developing a service quality model for private higher education institutions in Lebanon. Journal of Management and Marketing Review, 3(1), 2433

29. Kim, Y., Kim, K., \& Yun, D. (2003). Exploration and development of SERVQUAL. Asian Journal on Quality 4(1), 116-130,

30. Ladhari, R. (2009). A review of twenty years of SERVQUAL research, (2), 72-198.

31. Leonnard (2018). The performance of SERVQUAL to measure service quality in private university. Journal on Efficiency and Responsibility in Education and Science, 11(1), 16-21.

32. Lewis, R. C. \& Booms, B. H. (1983). The marketing aspects of service quality. In Berry, L., Shostack, G., and Upah, G. (eds.), Emerging perspectives on services marketing, American Marketing Association Chicago, 99-104.

33. Markovic, S. \& Raspor, S. (2010). Measuring perceived service quality using SERVQUAL: a case study of the Croatian hotel industry. Management, University of Primorska, Faculty of Management Koper, 5(3), 195209.

34. McDonald, G. W. (1981). Structural exchange and marital interaction. Journal of Marriage and the Family, 43, 825-839.

35. Michael C. Handrinos, M. C., Folinas, D., \& Rotsios, K. (2015). Using the SERVQUAL model to evaluate the quality of services for a farm school store. Journal of Marketing and Consumer Behavior in Emerging Markets, 1(1), 62-74.

36. Mosmann, C., Wagner, A., \& Féres-Carneiro, T. (2006). Qualidade marital: Mapeando conceitos. Paidéia (Ribeirão Preto), 16(35).

37. Muhammad Butt, M., \& de Run, E. C. (2010). Private healthcare quality: applying a SERVQUAL model. International Journal of Health Care Quality Assurance, 23(7), 658-673.

38. Neupane, R. \& Devkota, M. (2017). Evaluation of the impacts of service quality dimensions on patient/customer satisfaction: A study of private hospitals in Nepal. International Journal of Social Sciences and Management, 4(3), 65-176.

39. Obradović \& Čudina-Obradović (1998) Obradović, J., \& Čudina-Obradović, M. (1998). Bračna kvaliteta: Poimanje, uzroci i posljedice [Marital quality: Definition, causes and consequences]. Društvena Istraživanja, 7(45), (36-37), 659-682.

40. Ok, S. \& Hengsadeekul, T. (2018). Customer satisfaction on service quality of bus transport: a survey of passengers from Phnom Penh to Poipet in Cambodia. Journal of Social Science Studies, 5(2), 114-131.

41. Ok, S., Suy, R., Chhay, L, Choun, C. (2018). Customer satisfaction and service quality in the marketing practice: a study on literature review. Asian Themes in Social Sciences Research, 1(1), 21-27.

42. Oliver, R. L. (1980). A Cognitive Model of the Antecedents and consequences of satisfaction decisions. Journal of Marketing Research, 17(4), pp.460-69.

43. Oliver, R. L. (1997). Satisfaction: A behavioral perspective on the consumer. New York: McGraw-Hill.

44. Olson, J., Dover, P. (1979), Disconfirmation of consumer expectations through product trial. Journal of Applied Psychology, 64, 179-189. 
45. O’neill, M., \& Palmer, A. (2003). An exploratory study of the effects of experience on consumer perceptions of the service quality construct. Managing Service Quality, 13(3), 187-196.

46. Pamatmat, F, V., Dominguez, L. L., Pamin, C. D., \& Daran, A. M. (2018). Service quality dimensions of a Philippine state university and students' satisfaction: Bridging gaps to excellence. International Journal of Advanced Research, 6(7), 673-681.

47. Parasuraman, A., Berry, L. L., \& Zeithaml, V.A. (1991). Perceived service quality as a customer based performance measure: an empirical examination of organizational barriers using an extended service quality model. Human Resource Management, 30(3), 335-64.

48. Parasuraman, A., Zeithaml, V., \& Berry, L. L. (1985). A conceptual model of service quality and its implications for future research. Journal of Marketing, 49(Autumn), 41-50.

49. Parasuraman, A., Zeithaml, V., \& Berry, L. L. (1986). SERVQUAL: A multiple-item scale for measuring customer perceptions of service quality. Report No. 86108, Marketing Science Institute, Cambridge, MA.

50. Parasuraman, A., Zeithaml, V., \& Berry, L. L. (1988). SERVQUAL: A multiple-item scale for measuring consumer perceptions of service quality. Journal of Retailing, 64(Spring), 12-40.

51. Parasuraman, A., Zeithaml, V., \& Berry, L. L. (1991). Refinement and reassessment of the SERVQUAL scale. Journal of Retailing, 67(4), 420-50.

52. Parasuraman, A., Zeithaml, V. and Berry, L. L. (1994), "Reassessment of expectations as a comparison standard in measuring service quality: implications for future research", Journal of Marketing, Vol. 58, January, pp. 111-24.

53. Patterson, P. G., Johnson, L. W., \& Spreng, R. A. (1997). Modeling the determinants of customer satisfaction for business-to-business professional service. Journal of the Academy of Marketing Science, 25(1), 4-17.

54. Poor, M. H., Poor, M. A., \& Darkhaneh, M. A. (2013). The quality of service and its importance in service organizations. Arabian Journal of Business and Management Review (OMAN Chapter), 3(3), 34-37.

55. Rehaman, B. \& Husnain, M. (2018). The impact of service quality dimensions on patient satisfaction in the private healthcare industry in Pakistan. Journal of Hospital \& Medical Management, 4(1), 1-8.

56. Robles, T. F., Slatcher, R. B., Trombello, J. M., \& McGinn, M. M. (2014). Marital quality and health: A meta-analytic review. Psychol Bull, 140(1), 1-80.

57. Sabatelli, R. M. (1984). The marital comparison level index: A measure for assessing outcomes relative to expectations. Journal of Marriage and the Family, 46, 651-662.

58. Sabatelli, R. M., \& Pearce, J. T. (1988). Exploring marital expectations. Journal of Social and Personal Relations. 3, 301-321.

59. Saghier, N. M. E. (2015). Managing service quality: Dimensions of service quality. International Journal of African and Asian Studies. 9, 56-64.

60. Scheeren, P, de Andrade Vieira, R. V., Ribeiro Goulart, V., \& Wagner, A. (2014). Marital quality and attachment: The mediator role of conflict resolution styles. Paidéia (Ribeirão Preto), 24(58).

61. Schoebi, D., Karney, B. R., \& Bradbury, T. N. (2011). Stability and change in the first 10 years of marriage: does commitment confer benefits beyond the effects of satisfaction? Journal of Psychology and Social Psychology, 102(4), 729-742.

62. Scorsolini-Comin, F., \& Santos, M. A. (2009). Casar e ser feliz: Mapeando a mensuração da satisfação marital. Psico, 40(4), 430-437.
63. Shekarchizadeh, A., Rasli, A. \& Huam, H. T. (2011) SERVQUAL in Malaysian universities: perspectives of international students. Business Process Management Journal, 17(1), 67 - 81

64. Sheth, J. N., \& Mittal, B. (2004). Customer behavior: A managerial perspective ( $2^{\text {nd }}$ ed.). South-Western, USA.

65. Smith, R., \& Houston, M. J. (1982). Script-based evaluations of satisfaction with services. In Emerging Perspectives on Services Marketing, L. Berry, G. Shostack, and G. Upah, eds., Chicago: American Marketing, 59-62.

66. Spanier, G. B. (1976). Measuring dyadic adjustment: new scales for assessing the quality of marriage and similar dyads. Journal of Marriage and Family, 38(1), $15-28$.

67. Spanier, G. B., \& Lewis, R. A. (1980). Marital quality: A review of the seventies. Journal of Marriage and Family, 42(4), 825-839.

68. Spring, R. A., MacKenzie, S. B., \& Olshavsky, R. W. (1996). A reexamination of the determinants of consumer satisfaction. Journal of Marketing, 60(3), 15-32.

69. Spring, R. A., \& Page, T. J. Jr. (2003). A test of alternative measures of disconfirmation, Decision Sciences, 34(1), 31-62.

70. Syahir, F., \& Hudrasyah, H. (2014). The influence of service quality dimensions on customer satisfaction and customer loyalty in Pt. June North Bandung area. Journal of Business and Management, 3(5), 546-556.

71. Umberson, D., \& Williams, K. (2005). Marital quality, health, and aging: Gender equality? The Journals of Gerontology Series B: Psychological Sciences and Social Sciences, 60, 109-113.

72. Yarimoglu, E. K. (2014). A review of dimensions of service quality models. Journal of Marketing Management, 2(2), 79-93.

73. Yoon, T., \& Ekinci (2003). An examination of the SERVQUAL dimensions using the Guttman scaling procedure. Journal of Hospitality and Tourism Research, 27(1), 3-23.

74. Zaim, H., Bayyurt, \& Zaim (2010). Service quality and determinants of customer satisfaction in hospitals: Turkish experience. International Business \& Economics Research Journal, 9(5), 51-58.

75. Zeithaml. V., Berry, L. L., \& Parasuraman, A. (1993). The nature and determinants of customer expectations of service. Journal of the Academy of Marketing Science, 21(I), 1-12. 